They were confident that good ideas, whatever their origin, got a fair hearing, and that bad ideas could be weeded out before they had gone too far. Some members of the committee suggested that the only pressure brought to bear on the projects was financial pressure. The witnesses agreed that financial pressure alone was enough to put a heavy constraint on defence research, but in addition there was an automatic weeding process.

Mr Eric Lubbock suggested that the British hovercraft industry had had less than fair treatment from the ministry. Although they had made a number of proposals, few had been taken up. Mr Stuart Watson, for the Nary, agreed that the industry had been "pestering us with ideas". The result had been to agree to the building of BH7 hovereraft for the Army and the Navy, although the Army version had now been cancelled because of the withdrawal from the Far East. As for bigger hovercraft, they would have to be shown to fulfil a real military requirement. $\mathrm{Mr}$ Lubbock thought this an extraordinary answer. Would the hovercraft not be suitable as a search vessel for submarines, or as a fast armed vessel ? The witnesses reiterated that all possible had been done to help the hovercraft industry.

\section{London's Water}

Tне bacteriology, chemistry and biology of London tap water are subjects which most Londoners must prefer not to have to think about when they drink their morning cup of tea. A grcat deal of work, however, has to be done before the water from the River Thames and the River Lee is even remotely drinkable and stringent standards are operated to make tap water as pure as possible. Some of the routine and research work done by the Water Examination Department of the Metropolitan Water Board during 1965-66 to achieve these standards is deseribed in the fortysecond report of the department just published (Metropolitan Water Board, 32s. 6d.).

Continuous sampling and testing is carried out to check the quality of supplies. In 1966 almost 133,000 samples were dealt with-the highest number of samples ever handled by the department. "Ideally all waters intended for drinking should show no coliform bacteria in $100 \mathrm{ml}$. and it should be the aim of every water undertaking to provide water of this quality", according to Report No. 71 of the Ministry of Housing and Local Governmont and the Ministry of Health. London water seems to pass the test-out of more than 11,000 samples of treated water lewving the board's filtration works and well stations in both 1965 and $1966,99.98$ per cent were 100 per cent bacteriologically pure as far as Escherichia coli was concerned. Results of the coliform test were not quite as good in 1966 as in $1965 ; 99 \cdot 68$ per cent of samples were free from coliform bacteria compared with a percentage of 99.88 in 1965 This slight decrease in purity can probably be explaincd, the department says, because a more sonsitive test for the isolation of coliform bacteria was introduced at the beginning of 1966 .

Detailed descriptions of the work of the various sections of the dopartment are given in the report. The bacteriological section has been continuing its examination of water for Salmonella organisms; their presence in the water after storage and primary filtra- tion and on the surface of slow sand filters suggests reinfection of the water by gulls. Salmonella organisms have also been isolated from detergent foam. The chemistry section has found that there has been a reduction of the residual amounts of synthetic detergent material in the board's river sources of supply after the complete substitution in packets of washing powder retailed in Britain of anionic detergents which are biologically degradable.

An important part of the department's work is concerned with public health, such as the examination of waterworks omployees for the detection of carricrs of waterborne diseases. It was reported in the previous annual report that a case of bilharzia had been found among the board's employees, and this has prompted spcculation as to whether the disease could possibly spread in Britain. It is thought unlikely but not impossible, and a note of warning is given on the careless introduction of snails - the intermediate hosts for the helminth parasite Schistosoma-from countries where the disease is endemic.

\section{No More Noise?}

From July this ycar, British motorists will be subject to yet another roadside spot check. At present drivers have to proceed soberly, in a safe vehicle and at a moderate pace, but by the summer they will have to be quiet as well. Although the regulations announced this weck by Mrs Barbara Castle, Minister of Transport, put the maximum allowed decibels at higher levels than those recommended by the 1962 Wilson Committee on Problems of Noise, the limits are experimental and may well be lowered in the future. Noise meters will be used in much the same way as the radar speed ehecks, with police stopping the vehicles which pass the set limits- $90 \mathrm{db}$ for motor cycles over $50 \mathrm{cc}, 87 \mathrm{db}$ for passenger cars and $92 \mathrm{db}$ for heavy goods vehicles, agricultural vehicles and buses. During the initial period drivers of lorries with burnt-out silencers and car fiends with "organ-pipe exhausts" will be cautioned only, but later on, offenders will be liable to fines of up



The noise meters are said by the Ministry of Transport to be very accurate. They will be calibrated by approved laboratories and checks will be made from time to time against gadgets with standard noise output. A three decibel allowance is made in the noise limits for roadside tests to allow for such things as sounds reflected from other vehicles. From 1970, all vehicles will have to be constructed in such a way that they do not exceed the noise limits when tested at full throttle. The two year time lag is being allowed to give manufacturers time to adapt their models.

\section{Golden Touch}

The Royal Institution launched last year an appeal for $£ 225,000$ and did it so successfully that $£ 270,000$ has already been reccived and the money is still coming in. The donors include some 300 foundations, companies and individuals. The money is to be spent on building a new lecture theatre and museum, renovating the present theatre and laboratories and expanding the institution's educational facilities.

The Royal Institution was founded in 1799 by a native of Massachusetts, Count Rumford, for the pro- 
motion of science and the diffusion and extension of useful knowledge. Among its resident professors have been Davy and Faraday, and its present director is Professor George Porter. The current functions of the Royal Institution, as Professor Porter explained last week to the clinking of champagne glasses, are to serve as a society for the advancement of scicnce, as a national archive for the history of science, as a theatre for scientific lectures and meetings and as a research laboratory. The enviable success of the institution's appeal will no doubt help.

\section{Computer Control}

In the future, British industry will apply computers to production and stock control to the same extent as they are now used in accountancy. This was the theme of a symposium organized by the British Computer Society in London, on March 20. More than 1,000 delegates heard from British and American experts how computers can be applied to the scheduling of production on the shop floor, to the control of materials needed in the manufacturing processes and to the efficient stocking of the finished product.

There still seems to be a variety of pitfalls in the introduction of computers into production controlnot the least the problems associated with people. One of the speakers pointed out that two of the commonest mistakes made by management are the failure to take into account the limits of comprehension of employees and the neglect of those parts of the control system which are placed outside the computer. This means that more attention needs to be paid to gathering data for the computer, and to the way in which the computer output is used by management and personnel on the shop floor. And, not unnaturally, there is always the lurking fear that people are being replaced by machines.

Several delegates to the symposium seemed doubtful whether computer production and stock control systems had reached the stage of making themselves pay. There seems to be no clear-cut answer to this - obviously it is difficult to estimate the financial saving made by benefits such as less capital tied down in stock and work-in-progress, better delivery dates and so on which are claimed by advocates of computer systems. Nevertheless, more and more manufacturers are turning to computer systems, especially in the United States, which is clearly showing the way in this field.

One of the questions which the symposium tried to answer was whether the smaller firm should go in for production control by computer when big organizations are obviously running into difficulties in this field. Mr B. G. Roberts, computer development manager for Belling and Lee Ltd, defined the smaller firm as one with less than $£ 60,000$ per annum to spend on data processing during the first few years of operating a computer. $\mathrm{He}$ made the point that although the amount of data to be dealt with is less than in a larger company, the number of processes through which the data has to go may be just as great. Because the data handling procedures rather than the bulk of data provide many of the problems, and because big organizations have the resources to handle large amounts of data, it seems that small firms are less likely to be successful in introducing a computer than large ones.
Nevertheless, the chairman of the symposium, $\mathrm{Mr}$ W. G. E. Hulse, who is manager for production planning and material control at Standard Telephones and Cables, said in his summing-up that the emphasis in the future will be on the smaller companies. Because there are common ingredients to the production problems of many companies working in the same field, there is a need for co-operation in setting up computer centres. This poses problems in the security of business information but, as $\mathrm{Mr}$ Hulse pointed out, companies already rely on the confidential nature of bank accounts so why not trust computer centres in the same way?

\section{New Ideas}

THE emphasis was once again on the small firm at a conference with the title "Getting New Ideas off the Ground" held in London on March 21. Arranged by the Institute of Directors in association with the National Research Development Corporation, its aim was to tell senior management about the NRDC and the way it can help industry. The NRDC was set up in 1948 after it was realized how much had been lost by the failure fully to exploit commercially the discovery of radar and penicillin as well as many other discoveries pioneered in Britain. Its aim is to provide support for technological developments of potential commercial importance and to encourage industry to adopt new methods and products invented in government and university laboratories and elsewhere.

Sir Donald Stokes, chief executive and deputy chairman of British Leyland Motor Corporation, said in his opening address that no firm, however large or however small, need have any hesitation in putting its problems to the NRDC for consideration. He admitted that management was still far too stuffy about new ideas and was reluctant to give revolutionary thoughts a trial.

The message of the conference was that small firms should not be reticent in using the NRDC. Clearly large companies are aware of the NRDC and several of them are using its facilities, but the organizers felt that the functions of the NRDC needed emphasizing to the smaller firm.

\section{Data Centre for Oceanographers}

THe Natural Environment Research Council is to set up a British Oceanographic Data Service at the National Institute of Oceanography, Godalming. The head of the unit will not be appointed for another three months or so, but a steering committee of nine members has been announced and it had its first meeting last week. The chairman of the steering committee is Dr G. Deacon, director of the National Institute of Oceanography. As with many other subjects there is an increasing amount of data which needs handling in a systematic way. It is hoped that the centre will use modern methods of data storage-punched tape, a computer, and so on, and that it will have telex links with other oceanographic and research institutions.

This will not be the first oceanographic data centre in the world. There is one at Copenhagen run by the International Council for the Exploration of the Sea, and others in Hamburg and Ottawa, for example. The idea now is to have national data banks co-ordinating 